\title{
The Meaning of Water Environment for Stilt Houses on the Musi Riverbanks, Palembang
}

Ari Siswanto $^{1 *}$, Ira Kusumawaty ${ }^{2}$

${ }^{1}$ Department of Architecture Faculty of Engineering, Universitas Sriwijaya, Kampus Indralaya Jalan PalembangPrabumulih KM 32 Indralaya, Ogan Ilir, South Sumatra, Indonesia

${ }^{2}$ Politeknik Kesehatan Kemenkes Palembang, Jl. Jenderal Sudirman KM 3,5, Palembang, South Sumatra, Indonesia

*Corresponding Author: ariesiswanto@ft.unsri.ac.id

Article history

\begin{tabular}{llll} 
Received & Received in revised form & Accepted & Available online \\
16 May 2021 & 11 September 2021 & 13 September 2021 & 18 September 2021 \\
\hline
\end{tabular}

Abstract: Water functions are very diverse for humans for daily needs such as drinking water, bathing, agriculture, development, aesthetics, and lower temperatures. Palembang is a lowland area dominated by wetlands, tidal swamps, and rivers. The types of houses on stilts on the banks of the Musi river are limas, Gudang, and Chinese stilt houses which are always associated with the water environment. The construction of roads replacing the role of rivers has realized people that the water environment has an important meaning for the house on stilts. The research objective was to explore the meaning of the water environment from various aspects for residents, stilt houses, and their environment. This research method is a case study with data collection through interviews, observation, measurements, and taking photos. Data and findings were analyzed and juxtaposed with images in the field. The road construction has eliminated part of the function of the river and influenced the change in orientation of the house on stilts. In conclusion, respect for the water environment including rivers has decreased, causing the quality of the river to decline, and the house on stilts cannot take advantage of the existence of the water environment optimally.

Keywords: water environment, house on stilts, river

\section{Introduction}

Traditional houses in South Sumatra are generally wooden houses on stilts. Stilt houses are built in wetlands, lowlands, tidal marshes, riverbanks, and in mountainous and highland areas. The types of stilt houses in Palembang that can be classified as traditional houses are the limas, the Gudang, and the Chinese stilt houses.

Based on the ulu-ilir concept, houses outside the Palembang area are called ulu houses. Various house typologies are different from the ulu house. Most of the old settlements in South Sumatra were on the banks of or near rivers due to their strong dependence on rivers.

The human need for water availability cannot be denied that it is a very crucial need. Humans must very well regulate daily water balance throughout their lifespan despite changes in biological development and exposure to stress to hydration status. Acute or chronic body water deficit occurs when intake is reduced or losses increase [1]. Drinking water is a determinant of the health of the human body [2].

Contaminated drinking water and poor sanitation are linked to the transmission of diseases such as cholera, diarrhea, dysentery, and polio. Families play a role in making efforts to fulfill drinking water, including families in Palembang [3].
Access to drinking water cannot be separated from the type of house occupied by the family.

The types of houses on stilts in Palembang were limas, Gudang and Chinese stilt houses if they were located on the riverbanks and had an orientation facing the river, this was because the river was the main transportation route for the South Sumatra region including Palembang at that time [4]-[6]. Until now, the Musi River still functions as a transportation route connecting Palembang with the hinterland (Ulu area) as well as with other islands by sea through the Bangka Strait.

The people of South Sumatra have a riverine culture, old settlements are generally located on the banks of rivers that can function as transportation routes [7]-[11]. Sustainable community life, including water needs and economic and agricultural activities, is dependent on rivers and water [4][10] [12]. In addition, the river culture is made clear with the tribes in South Sumatra who use river names such as the Komering, Ogan, Lematang, Rawas, Enim, Rupit, Lake, and Daya tribes [13].

Furthermore, among the people of South Sumatra the terms Ulu, Ilir, Darat, and Laut are known, traditional people are not familiar with the terms North, East, South, and West. The concept of ulu-ilir in South Sumatra does not always mean upstream-downstream but can mean something such as city-village, the center of government-inland, and 
trade-agriculture [9][14].

The influence of the existence of large rivers, small rivers, and creeks has a very important meaning for people who live on the riverbanks so that it has led people to build stilts houses facing the river. The orientation of the house on stilts towards the river commonly known as the waterfront area has been carefully considered [11]. Therefore, the orientation of the house on stilts by the river does not point to one of the compass directions as this is not the main consideration. The issues are returning the orientation of the houses on stilts to the river so that the environmental function of the river becomes better and has a positive impact on houses on stilts by the river.

The research objective was to explore the meaning of water environment for the house on stilts from various aspects. Water and rivers have an important meaning for humans for daily needs, health, transportation, and trade, and are part of the concept of building design including the house on stilts.

\section{Material dan Methods}

This research used a case study method. The object of research was several houses on stilts (limas, Gudang, and Chinese houses on stilts) which are located on the Musi riverbanks, in the Seberang Ulu and Seberang Ilir areas of Palembang. The case study research approach is used because the analysis can be carried out intensively for research on stilt houses located in several locations [15]. The purpose of the research was to build a complete narrative based on complete descriptive information from the object of the research.

Field data was collected through observation, documentation measurement, and description as well as interviews. Participants who are the target of the interview are owners, residents, and community leaders related to the limas, Gudang, and Chinese houses on stilts. The number of houses on stilts on the Musi riverbanks in this study consisting of 5 limas, 3 Gudang, and 2 Chinese houses on stilts. This case study includes 10 houses on stilts that are still oriented towards the river, while 20 respondents include 10 owners of houses on stilts studied and 10 other respondents are community leaders who know about the chronology of changes in the orientation of houses on stilts due to road construction around riverbank settlements. The houses on stilts are old houses that have been inhabited for generations so that the owner of the house can talk about the condition of the river in front of his house. The story is told from generation to generation

Data and findings were analyzed and then juxtaposed with images in the field well as interviews. Participants who are the target of the interview are owners, residents, and community leaders related to the limas, Gudang, and Chinese houses on stilts.

\section{Results and Discussions}

\subsection{Settlement Patterns}

The old settlements that developed on the riverbanks in the South Sumatra region can still be witnessed today, for example on the riverbanks of the Musi, Komering Ogan, Lematang, and Rawas rivers. Initially, settlements developed along the riverbanks on one side and on both sides of the river forming a linear, longitudinal pattern [4][5]. The elongated pattern of laying houses is because the community takes advantage of the potential of the river to support their daily life.

The choice of location for settlements on the riverbanks even though the river is small is the right choice because the community depends on the river not only for their daily water needs but also for transportation, trade, and community livelihoods [16][17].

The initial settlements were formed from a row (layer) of houses built along the riverbanks. In this initial condition, there are two possible patterns, namely the first pattern, the house is built right on the riverbanks or partly in a water body (Figure 1). The second pattern is that between the house on stilts and the river there is still an open area or space so that the house on stilts does not directly stick to the river (Figure 1). The existence of open space which will then turn into a road indirectly indicates a river boundary line or a building setback which is the boundary of the area between the dwelling and the river [18]. 


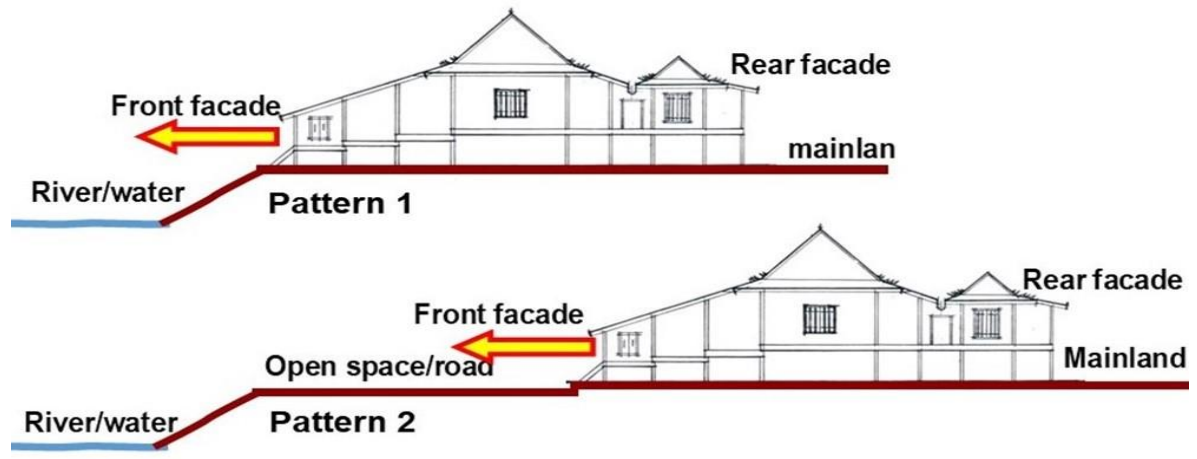

Figure 1. The Pattern of the Location of the Traditional Settlement Towards the River

Stilt house settlements also had developed on the banks of small rivers around the Kuto Besak Palace (Fortress). The orientation of the house facing the river. The old settlements on the riverbanks in Palembang generally consisted of large and magnificent stilt houses and this indicated that the homeowners had a respectable status.

The growing population needs houses and land for their settlements. If a single line linear pattern is not possible, the house will be built on the second layer. Between the two rows of houses, there is an open space that allows this space as a place for residents to interact in the settlement. The development of settlements depends on the local topography, if the development of an a-second row pattern is not possible, the community will form a row pattern perpendicular to the river channel or form a cluster pattern.

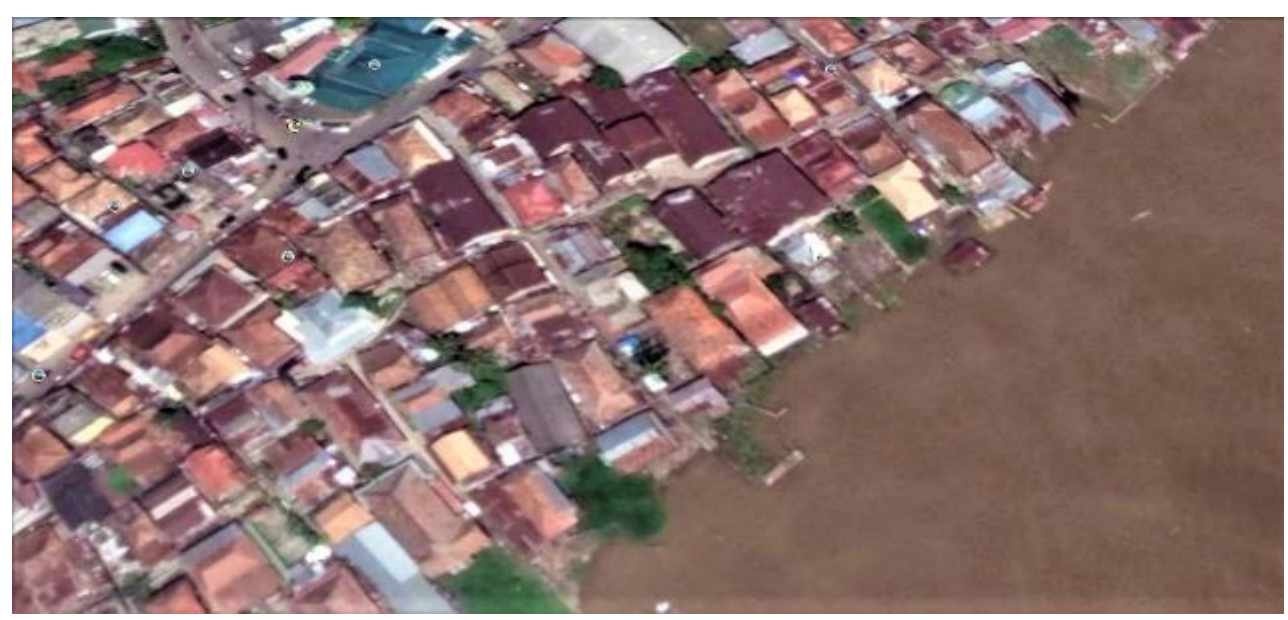

Figure 2. Riverbank Settlements with High-Density Levels (Source: Google map).

Settlements that are built following the pattern parallel to the river still allow the orientation of the house to the river, although it is not optimal because there are houses in front of the river [4][5]. The construction of houses in settlements on the riverbanks is taking place increasing intensively, densely, and irregularly so that it tends to become slum settlements (Figure 2).

Settlement patterns are changing slowly with the construction of land roads that can be better utilized from rivers because the roads do not influence by tidal water and have access to various directions. Initially, the road was built parallel to the river right on the riverbank or in the area between the first and second rows of settlements. If the road is built on the riverbank, the orientation of the house will remain unchanged facing the river [4][6]. On the other hand, if the road is built behind the first row of houses, it is almost certain that the orientation of the house will change to face the road instead of the river (Figure 3).

Road construction changes settlement patterns because residents need easy access to land roads that do not depend on tidal conditions for river flows. In addition, the value of the land on the side of the road is increasing so that it can indirectly increase the status of the homeowner. On the other hand, riverside settlements are less desirable and tend to become a slum. These unfavorable conditions have an indirect effect on river conditions [19]. 


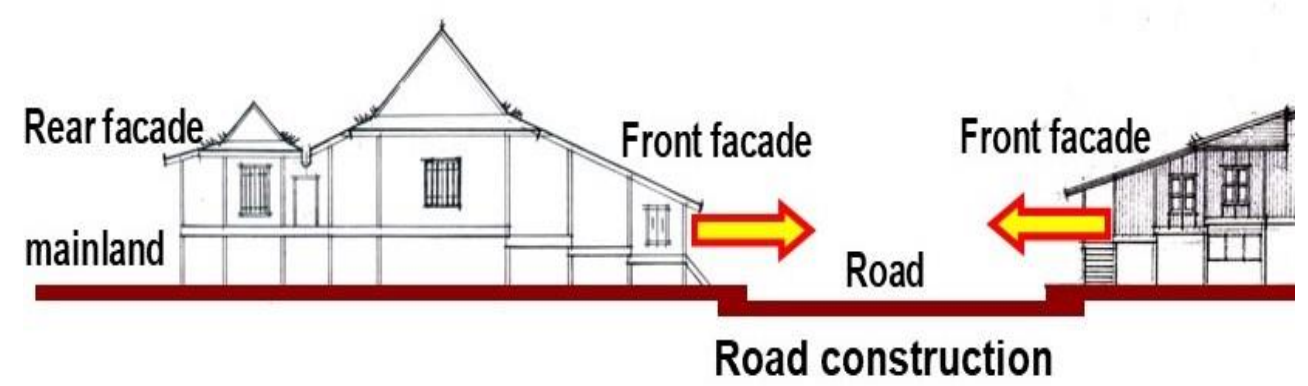

Figure 3. Effect of Road Construction on Stilts Houses' Orientation

During the Dutch colonial period, several tributaries of the Musi river around the Kuto Besak Fortress area were reclaimed and developed into roads. Therefore, nowadays the house on stilts looks like it still faces the road that was once a backfilled river. Thus, some houses on stilts do not change the orientation of the front facade of the house. On the other hand, the change in the orientation of the house from the river to the direction of the road causes the river to become less valued. This causes the function of the river to change.

\subsection{House on Stilts}

One type of house on stilts is a limas house, which was originally a Palembang aristocrat house, a stilt house with terraces that has a limas-shaped roof. As a noble house, the limas house has a large size, generally, it has a width of more than $15 \mathrm{~m}$, the plan of the limas house is a rectangle extending backward. After the Dutch succeeded in defeating SMB II, limas houses began to spread to Seberang Ilir and Seberang Ulu in Palembang as well as to various areas in South Sumatra.

Generally, the Limas houses were still built on the banks, near rivers, or in water bodies (Figure 4). If the house on stilts is located on a body of water, it will be clear at high tide that the house on stilts is surrounded by water. The terrace of the house is located above a body of water and has a free view of the river as if without borders. The front wall, which is shaped like a wooden trellis (wooden bars), can be opened or removed so that the inside of the house seems to merge with the outside towards the river (Figure 4).

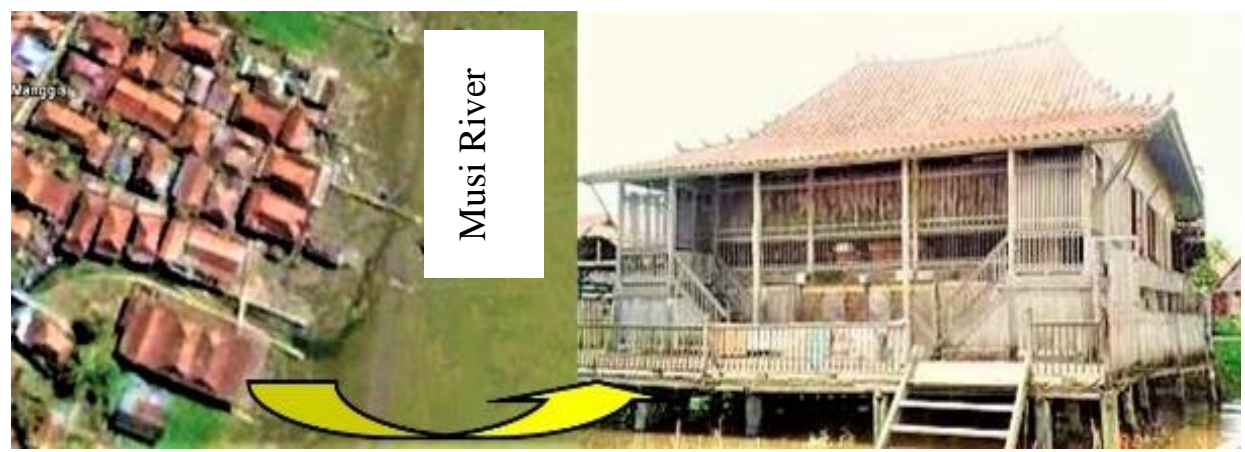

Figure 4. The Limas House on The Musi Riverbank (Source: Google map, left and author's research, right)

The Gudang house, which is one type of house on stilts, has a floor of one height because it does not have steps like a limas house. The Gudang house is a house owned by ordinary people, which is simpler than the limas house. However, some houses on stilts have interiors and carvings and ornaments like a limas house, because the owners are respected people. The Gudang built on the riverbanks have terraces or are ferocious on the Musi riverbanks so that the orientation of the Gudang house is towards the river. The terrace of the house has a wide view towards the river and gets the maximum breeze and natural light (Figure 5). a terrace or balcony that has open views of the river is a favorite relaxing place for residents of the house on stilts The existence of the wide Musi River has been utilized well by homeowners. 


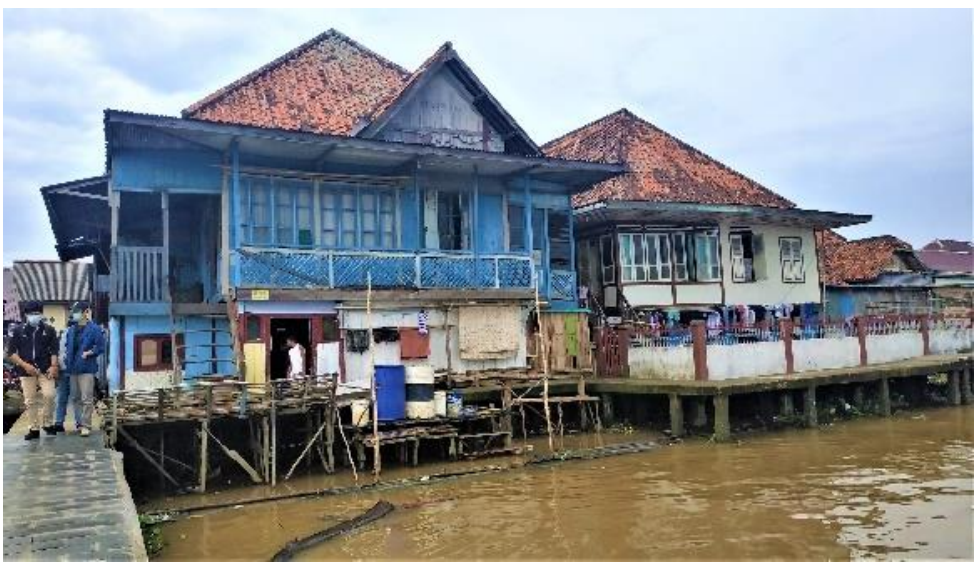

Figure 5. The Gudang House on The Musi Riverbank

The stilt houses in this study have clean water bodies in the sense that river water is not covered with garbage when compared to its surroundings. However, the quality of water for example in terms of water clarity is the same as others. The river body in front of the house is maintained because it still functions, for example for water transportation.

Apart from accessibility from the river by boat, homeowners can take advantage of the beautiful view towards the river and get conditions of thermal comfort or lower temperatures due to the wind blowing without being obstructed by buildings or trees. The tropical climate, which is characterized by scorching heat, high temperature, and humidity, can be reduced due to wind gusts from the direction of the river. Wind gusts through the surface of the river water can lower the temperature in a micro-way [18]. This condition will be more comfortable for the occupants of the house on stilts at night.

After the Dutch colonial government came to power in Palembang, ethnic Chinese groups living in raft houses were allowed to build houses on the land. They built a house on stilts with the orientation of the house facing the Musi river. Most Chinese people remain dependent on rivers because of their trading activities through rivers. Until now, a large Chinese house on stilts is still on the Musi riverbanks, surrounded by marsh plants (Figure 6).

During its development, road construction also had a major influence on the Chinese stilt houses located on the riverbank. Many trading activities are carried out using rivers which resulted in the house on stilts by the river being neglected or abandoned. This condition is getting worse because the neighborhood tends to be slim due to the limited infrastructure in the swamps.

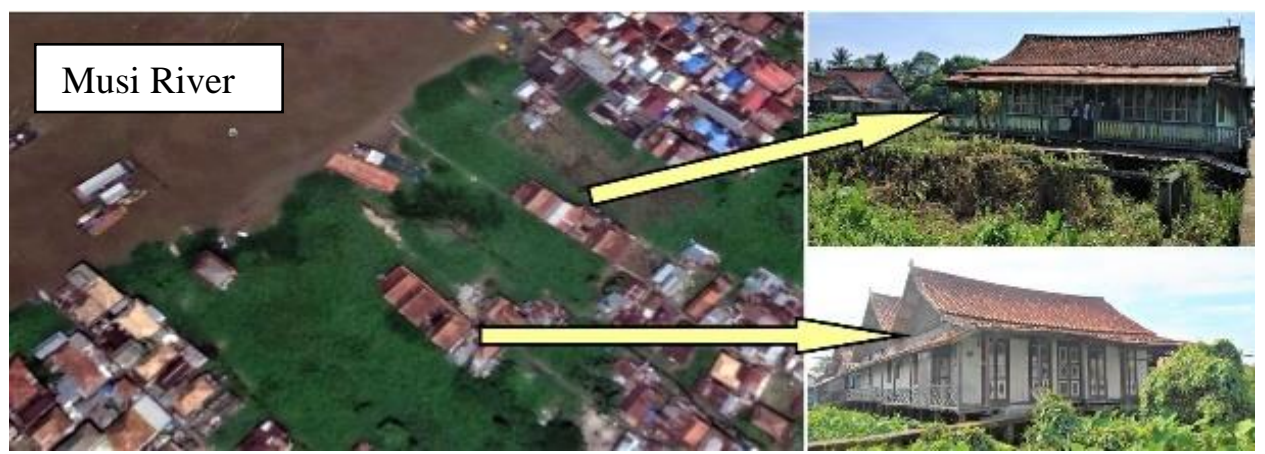

Figure 6. Chinese House on Stilts on The Musi Riverbanks (source: Google map, left and author's research, right)

In general, some of the houses on stilts of China have now changed ownership, become the property of local communities or their heirs who cannot move from the house. This condition occurs due to, among others, the construction of roads, old residential roads that cannot be passed by cars, or trade activities that are no longer dependent on river routes. The old settlements were getting denser and tending to be slum so that water in the form of rivers began to lose its meaning. The condition of the river is degrading and becomes a back area that is becoming increasingly shallow, dirty with garbage, and not being cared for as before. This is because the stilt house has been reoriented to turn its back to the river.

In general, limas, Gudang, and Chinese houses on stilts located on the Musi riverbanks have an orientation facing the river with the front side being a terrace or garage with one or two entrances [9]. If the front of the house on stilts utilizes the body of the river, then the terrace of the house can function as a Tango Rajo, where the boat is docked and tied to the 
terrace. The orientation towards the river has several advantages by exploiting this natural potential.

\subsection{Water Environment Function}

In this paper, what is meant by the definition of water environment in a broad sense is in forms such as seas, lakes, retention ponds, rivers, water sources, and clean water. Therefore, water in different forms will have different or specific functions for humans. Water will remain an important part of human life [1][2]. Naturally, rivers have very diverse functions for nature and living things, among them are the balance of water systems, daily human needs, agriculture, fisheries, transportation, and trade [5][10].

Rivers that have a function as trade routes and generally empties into the east coast of Sumatra have important functions as previously mentioned [8][20].
These large rivers have become the location of choice for building settlements along river banks which are generally still developing today [6][10]. Physically, the water environment is a necessity for human life to carry out daily activities and to ensure the sustainability of life in their respective environments.

Clean water is a daily necessity besides maintaining human health and the environment (Figure 7). Availability of water in quantity and quality, especially clean water, can maintain public health and cleanliness of the residential environment [1]. In addition, in the form of rivers, water has a broader function including transportation, accessibility, food sources, livelihoods, and natural resources [10]. Therefore, it is understandable that many traditional settlements in South Sumatra were established on the banks or near rivers.

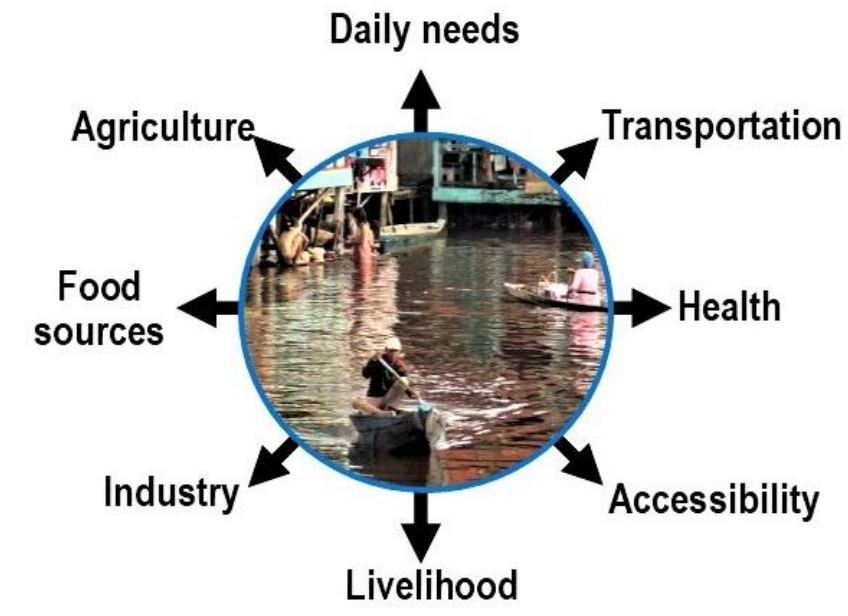

Figure 7. The Function of Water Environment for Human Life [1][2][8][20][21].

It was realized that the house on stilts was located on the bank of a river or a tidal marsh, at that time the owner of the house provided 2 water jars near the stairs. Water is used to wash feet and hands before entering the house. This is related to the cleanliness and health of a person before entering the house on stilts. In addition, the wind can blow under the floor (under) of the house on stilts which gives a thermal comfort effect in addition to the fact that the floor is not damp [22]. The house on stilts which is located on the riverbank can take advantage of natural potentials such as wind gusts, natural light, and good views of the river for mental and physical health. Participants said that the fresh air and natural light obtained as well as getting a beautiful and spacious view from the surface of the river can refresh one's soul. The dynamic sight of the boats crossing the river is very interesting and can provide a pleasant atmosphere.

When constructing buildings including houses on the riverbanks, the homeowners or local builders have a preference for optimally utilizing the river to support the sustainability of a house that remains safe and comfortable [9][18][21]. In the past, rivers were not subject to significant pollution. Therefore, the dependence on rivers was very large for traditional communities. However, currently, settlement growth and economic activity are starting to slow down from the riverbanks. 


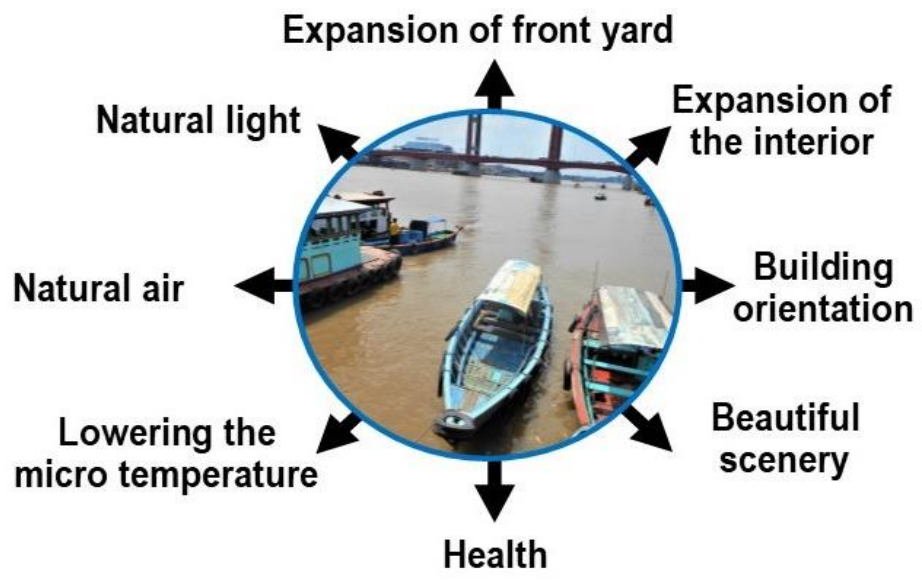

Figure 8. Water Environment as Important Elements in Building Design

Apart from having an important function for humans, water is also a principal element in the planning of a building adjacent to water such as rivers (Figure 8). In the context of building design, things related to the water environment generally have beautiful scenery, such as seas, lakes, rivers, retention ponds, waterfalls, and water sources. Based on this philosophy, rivers are public property that will not be defined as land plots. Therefore, the river surface has no physical boundaries except imaginary. In their natural form, rivers do not have physical barriers such as fences or intentionally planted trees blocking one's view.

In open conditions, rivers provide flexibility for natural elements such as wind, fresh air, and natural air currents that can be used optimally for humans directly without significant obstacles [11][18]. Physical conditions without artificial objects except boats and ships are potentially important in the context as a planning element.

In short, when considered as an element of building design, the water environment (one of which is in the form of a river) is a natural potential that is an extraordinary gift to make building designs more beautiful and meaningful. Water can be considered in various aspects of planning such as the expansion of the yard, interior expansion, building orientation, beautiful sceneries, health, lowering microtemperatures, as well as air and natural light [18][21]. All these aspects are very important for the building design of a house on stilts because it has the advantage of the natural environment.

Based on the previous explanation, the water environment in this case the river, has a positive influence on the existence of stilts houses that are deliberately built near or on the riverbanks. The residents of the houses on stilts on the Musi riverbanks have experienced many benefits by including the river as an important element to consider when building their stilts houses. Thus, it can be said that water influences humans physically and psychologically for humans in addition to the needs of daily life, and the potential of water will affect the design of buildings including houses on stilts.

\section{Conclusion}

Traditional settlement patterns on the banks of the Musi river or in wetlands were the right choice of location at that time. Local people who have a river culture appropriately can make use of the river before road construction. The house on stilts is the right choice of traditional settlement type for riverine culture communities in South Sumatra who live in the upstream and downstream areas. Building wooden stilt houses on riverbanks have many advantages in the presence of water or water environment.

Water environment in various aspects has a very important meaning for human life as a living thing. The need for water for daily life besides its function is to support human life activities such as transportation, trade, fisheries, and industry. At a time when land roads developed, rivers were an ideal substitute for the traditional communities living on the riverbanks.

The philosophy of water is public property, besides that water has an important meaning for human life, it also has a very big influence on building design including stilt houses from various aspects. Constructing and designing buildings, including stilt houses by the river as riverfront area of the city, really consider the water environmental aspect. The aspect that is considered in this building design is that the water environment seems to be part of the house yard and can unite the integrated impression between the exterior (river area) and the interior (the inside of the house) through the openings in the front of the house. One way to appreciate the presence of a river which is a gift from nature is the orientation of the building towards the river. The orientation of the building towards the river will get a beautiful view and can affect psychological health. If someone takes advantage of the airflow and natural light from the direction of the river, this will have a positive effect on the health of the occupants of the stilt's houses. 


\section{References}

[1] M. N. Sawka, S. N. Cheuvront, and R. C. Iii, "Human Water Needs," Nutr. Rev., vol. 63, no. 6, pp. 29-39, 2019.

[2] P. Li and J. Wu, "Drinking Water Quality and Public Health," Expo. Heal., vol. 11, no. 2, pp. 73-79, 2019.

[3] I. Kusumawaty and A. Siswanto, "Air Bagi Kesehatan: Tantangan Serius Mewujudkan Tujuan Pembangunan Berkelanjutan," in Prosiding Seminar Hari Air Sedunia, 2019, pp. 52-59.

[4] R. Rahmitiasari, A. Sudikno, and K. E. Sari, "Perubahan Arah Hadap Bangunan pada Permukiman Tradisional di Tepi Sungai Kuin Utara, Banjarmasin," Plan. Urban Reg. Environ., vol. 3, no. 1, pp. 1-10, 2014.

[5] A. R. Afdholy, H. Hamka, and S. Winarni, "Tipologi Pola Tata Letak Rumah pada Permukiman Tepian Sungai Kota Banjarmasin," Pawon, vol. 5, no. 1, pp. 95-106, 2021.

[6] B. Wicaksono, A. Siswanto, S. Kusdiwanggo, and W. F. F. Anwar, "Change of Element Settlement in Musi Riverside Palembang," $J$. Phys. Conf. Ser., vol. 1198, no. 8, 2019.

[7] D. Hanafiah, Kuto Besak Upaya Kesultanan Palembangakkan Kemerdekaan. Jakarta: CV Haji MasAgung, 1989.

[8] D. Irwanto, "Sarana Transportasi Tradisional" Palembang, 2020.

[9] A. Siswanto, "Kearifan Lokal Arsitektur Sumatera Selatan bagi Pembangunan Lingkungan Binaan," Local Wisdom, vol. 1, no. 1, pp. 37-45, 2009.

[10] F. Fahrianoor and A. Sanjaya, "Konsep batang banyu pada masyarakat tepian sungai dalam menjaga keberlanjutan sungai di Kalimantan Selatan," in Prosiding Seminar Nasional Lingkungan Lahan Basah. 2021, vol. 6, no. 3, pp. $1-10$.

[11] I. C. Danilescu, "Study on the Architectural Projects of the Floating Structures for Housing and Leisure , along the Danube," Danubian Stud. Res., vol. 10, no. 2, pp. 224-234, 2020.

[12] H. Shahamat, "Formal Sustainability in Traditional Architecture of Iran According To Five Principles of Traditional Architecture of Iran," J. Appl. Environ. Biol. Sci., vol. 4, no. 1, pp. 100-110, 2014.
[13] A. Siswanto, Arsitektur Tradisional Sumatera Selatan \#1, I. Yogyakarta: Pohon Cahaya, 2020.

[14] J. Kathirithamby-Wells, "Hulu-hilir Unity and Conflict: Malay Statecraft in East Sumatra before the Mid-Nineteenth Century," Archipel, vol. 45, pp. 77-96, 1993.

[15] J. W. Creswell, Qualitative Inquiry \& Research Design Choosing among Five Approaches, Second. London: SAGE Publications, Inc, 2007.

[16] I. Y. Hadinata and I. Mentayani, "Karakter Arsitektur Tepi Sungai di Kampung Sasirangan Kota Banjarmasin," Info Tek., vol. 19, no. 1, pp. 87-100, 2018.

[17] B. Wicaksono, A. Siswanto, S. Kusdiwanggo, and F. W. F. Anwar, "Perubahan Orientasi Permukiman Tepi Sungai sebagai Pengaruh Eksistensi Sungai Musi Palembang," Lingkungan Binaan Indonesia, vol. 8, no. 629, pp. 86-94, 2019.

[18] F. Firmansyah, B. N. Kusuma, I. Prayuni, and A. Fernando, "Principles and concepts in designing tropical-shore settlement in estuary ecosystem, case study: Weriagar District , Bintuni Bay Principles and concepts in designing tropical-shore settlement in estuary ecosystem , case study: Weriagar District, Bintu,"Journal of Architecture and Urbanism vol. 42, no. 2, pp. 169-176, 2018.

[19] B. Wicaksono, A. Siswanto, S. Kusdiwanggo, and W.F.F. Anwar, "Cultural Approach of Sustainability in Dwellings Culture Riparian Community Musi River Palembang," Dimensi : Journal of Archit. Built Environ., vol. 43, no. 2, pp. 85-92, 2016.

[20] E. Wiyanarti, "River and Civilization in Sumatera's Historical Perspective in the 7th to 14th Centuries,"in IOP Conf. Ser. Earth Environ. Sci., vol. 145, no. 1, 2018.

[21] P. De-Joanna, "The Water for Climate Comfort in Architecture," in International Conference on Civil, Architecture and Sustainable Development, 2016, pp. 42-47.

[22] I. N. Ramdhani and Y. P. Prihatmaji, "Kolong di Arsitektur Nusantara," in SENADA Seminar Nasional Desain dan Arsitektur, 2021, vol. 4, pp. 184-196. 